\title{
MPRA
}

Munich Personal RePEc Archive

\section{Education Enrollment Rate vs Employment Rate: Implications for Sustainable Human Capital Development in Nigeria}

Adejumo, Oluwabunmi and Asongu, Simplice and Adejumo, Akintoye

January 2021

Online at https://mpra.ub.uni-muenchen.de/109903/

MPRA Paper No. 109903, posted 25 Sep 2021 08:57 UTC 


\title{
$\underline{\text { A G D I Working Paper }}$
}

\section{$\mathrm{WP} / 21 / 013$}

\section{Education Enrollment Rate vs Employment Rate: Implications for Sustainable Human Capital Development in Nigeria}

Forthcoming: International Journal of Educational Development

\section{Oluwabunmi O. Adejumo}

Institute for Entrepreneurship and Development Studies, Obafemi Awolowo University, Ile-Ife, Nigeria

E-mail:jumobum@gmaill.com

\author{
Simplice A. Asongu \\ African Governance Development Institute, \\ P.O Box 8413, Yaoundé, Cameroun \\ E-mail:asongusimplice@yahoo.com
}

\author{
Akintoye V. Adejumo \\ Department of Economics, Obafemi Awlowo University, \\ Ile-Ife, Nigeria \\ E-mail:adejumoakinvic@gmail.com
}


Research Department

\title{
Education Enrollment Rate vs Employment Rate: Implications for Sustainable Human Capital Development in Nigeria
}

\author{
Oluwabunmi O. Adejumo, Simplice A. Asongu \& Akintoye V. Adejumo
}

January 2021

\begin{abstract}
The study examines the dynamic interrelationships among the school enrolment rates and the rate of employment (via unemployment rates) in Nigeria. The study employed Autoregressive estimates and an unrestricted VAR approach to analyze these relationships. The study lends credence to the new-growth theory (i.e. endogenous models) that more investments in human capital, through education especially at higher levels, will allow human capital to evolve dynamically and increase long-run growth in Nigeria. This tendency engenders multiplier effects in stimulating sustainable development given that education-driven growth facilitates employment. The growth literature has been definitive on the role of human capital in achieving long-run economic growth. Therefore, investments in education have been identified as a vital channel for building human capital and achieving long run development objectives. Thus, in the nascent quest for sustainable development, this study takes the new growth theory a step higher by examining the modulating effects of educational-driven growth (i.e. via school enrolments rates) in setting the pace for employment patterns in Nigeria.
\end{abstract}

Keywords: Education, Employment, Human Capital, Enrolment, Development JEL Classification: I21; I31; O40; O55 


\section{Introduction}

Over the years, both at private and public levels, Nigeria has continuously invested in activities that can promote human capital development. This ranged from out-of-pocket educational investments at individual levels to macroeconomic budgetary allocations for educational development. Also, the government has come up with programmes that are consistent with global initiatives to promoting education for all, like the Millennium Development Goal (MDG) 4 on Universal Primary Education as well as the Sustainable Development Goal (SDG) 4 which aims at ensuring inclusive and equitable quality education and promoting lifelong learning opportunities for all (Asongu, Nnanna and Acha-Anyi, 2020a, 2020b). Some national programmes embarked on, included activities such as the Universal Basic Education, free feeding programmes in schools, educational subsidy scheme and the Tertiary Funding Scheme. In view of the expected benefits from education, which among others include positioning and qualifying graduates for better employment opportunities, there is the controversy in literature on the relevance of more and more formal education systems given the challenge of unemployment which remains a cancerous phenomenon in the process of development in Nigeria; thus, questionning the efforts of government and private individuals. (Obadan and Odusola, 2000; Okafor, 2011; Ajufo, 2013; Asaju, et al, 2014; Adejumo and Adejumo, 2017). Specifically, challenges such as graduate unemployment, employment mismatch, low productivity and underemployment has indeed challenged the continuous quest for more educational pursuit in Nigeria. For instance, according to the National Bureau of Statistics (2018), the unemployment rate in Nigeria averaged 10.63 percent from 2006 until 2017, reaching an all-time high of 19.70 percent in the fourth quarter of 2009 and a record low of 5.10 percent in the fourth quarter of 2010 (NBS, 2018). Also, youth unemployment in Nigeria rose from $9 \%$ in 1991 to $13.4 \%$ in 2017 (World Development Indicators, 2018). Thus, given the peculiar challenge of securing relevant employment placement, there has been prescriptions by the International Labour Organisation (ILO) imploring developing economies to embrace more technical education that can enhance self-employment as opposed to putting more emphasis on formal primary, secondary and tertiary education systems (Krueger and Lindahl, 2001; Ahmad and French, 2011). 
Educational investments are expected to follow a cumulative order of returns to growth and development in the light of the educational hierarchy of expected benefits. It is in view of these anticipations that the expected returns to growth via secondary education supersede those of preprimary and primary education. In the same vein, tertiary education returns are anticipated to exceed those from secondary educational training. However, while some studies have found a positive and long-run relationship between education and growth in Nigeria (Dauda, 2009; Lawal 2011), others such as a study by Adawo (2011) has established that while primary education contributed to growth, secondary and tertiary education dampened growth. Omojimite (2010) found no causal relationship between on the one hand, capital expenditure and education and on the other, primary school enrolment and economic growth in Nigeria.

Thus, in tackling unemployment challenges, the first puzzle that comes to mind is whether the different education enrollment rates (as distinct measures of human capital) impact unemployment differently. Next, is the relevance of education driven growth for employment; or the extent to which the presence of education modulates growth to address development challenges like unemployment. Therefore, while understanding that education is central in human capital formation as noted by the endogenous growth theory, more important is how education through growth can bring about sustainable human capital development; which motivates this study to look beyond just the education-growth nexus. The study in the literature closest to the focus of the present study is Ndiyo (2007) who examined the plausibility of investments in education in improving labour productivity and established a decline in real output in Nigeria. But by interacting the education and growth, labour outcomes can be more effectively situated within the growth theory. Therefore, taking the education-growth relations higher, we examine the capabilities of education that have influenced growth to improve livelihoods by creating employment or reducing unemployment. It is against this background that this study examines the education-employment relationship vis-à-vis economic growth; as well as the input-output dynamics on the interactions that exist between educational enrollment and the employment trend in Nigeria.

The rest of the study is structured as follows. Section 2 discusses the theoretical and empirical literature as well as stylized facts on the implications of education for unemployment. 
The data and methodology are covered in section 3. Section 4 presents and discusses the empirical results while section 5 concludes with implications and future research directions.

\section{Literature Review}

\subsection{Theoretical Review}

Solow (1956), in an exogenous growth model asserted that beyond the traditional labour and capital as factor inputs, technical progress was a contributor to growth. Mankiw, Romer and Weil (1992) built on the Solow's model by introducing human capital as one of the factor inputs for growth. Also, the new growth theories included educational investments as one of the determinants of human capital development for growth (Lucas 1988; Romer 1990; Quah and Rauch, 1990; Grossman and Helpman 1991; Rivera-Batiz and Romer 1991). Furthermore, a variant of the endogenous growth model of a dual economy argued how rich individuals achieve growth by not just allocating labour time only for their own production and knowledge accumulation, but also by training the poor individuals (Gupta and Chakraborty, 2004).

According to the human capital theory, educational investments are made in anticipation of greater future returns or value. Since knowledge is subject to increasing the returns because these are non-rival goods, some past studies have posited that the longer your studies or the more the training you are exposed to, the more the future benefits you are going to earn (Barro and Lee, 1993; Romer, 1991; Benhabib and Spiegel, 1994; McMahon, 2009; Bowen, 2018). Also, this position of acquiring education and its implication for enhancing growth, productivity and employment has been situated in the growth literature. Specifically, the endogenous growth theory emphasizes "innovation-based" growth models. The model of Romer (1990), which stated aggregate productivity as a function of the degree of product variety, proposed elements of growth namely: capital, labour (unskilled labour), the further addition of human capital (as measured by the number of years of education), and new ideas (innovation). Romer's contribution to the endogenous growth model came through the analysis of research and development which yielded the perspective that long-run growth in part depends on the level of human capital. The underlying assumption is that human capital is a key input in development and the production of new ideas. Specifically, the endogenous model posits that economic growth is an offshoot of endogenous human capital activities and not external forces. Therefore, 
human capital development should be an inherent phenomenon contributing to growth and stimulating productivity. Thus, the centerpiece of endogenous growth theory is the role knowledge plays in contributing to human capital development to making growth possible.

Although other components of human capital (e.g. health, capabilities) have distinct impacts on economic growth, education remains a vital channel for economic development. Again, education alone is obviously not enough to solve the world's problems, but it remains an essential factor in creating and stimulating development solutions. Hence, based on the models of new growth theory, it can be inferred that education is an important input in the creation of new ideas; and this mechanism provides an appreciative (innovative) mechanism for generating new opportunities for employment, both in the short and long-runs. Thus, the endogenous growth theory predicts positive externalities and spillovers for development and even sustainable development for a high value-added knowledge economy.

\subsection{Empirical Review}

Empirical studies on nexuses between human capital, education and growth have been on a continuous debate. Following a list of some of these studies in Table 1, there is yet no consensus on how various education levels affect growth in different regions across the world. Despite these debates, some of these findings have informed policy decisions for economic growth in different economies of the world. However, beyond economic growth, there are some more fundamental issues on employment that could question the benefits or otherwise of acquiring education for development and sustainability; which is the crux of this study. 
Table 1: An Over-view of Education-Growth Literature

\begin{tabular}{|c|c|c|}
\hline Authors & Focus & Results \\
\hline $\begin{array}{l}\text { Liu and Armer } \\
\text { (1993) }\end{array}$ & Taiwan & $\begin{array}{l}\text { Primary and Junior-high had an effect on growth; but } \\
\text { secondary-high and college had no significant effects on growth }\end{array}$ \\
\hline $\begin{array}{l}\text { Barro and Lee } \\
\text { (1993) }\end{array}$ & Cross-Country & Positive effects between education and growth \\
\hline $\begin{array}{l}\text { Tallman and Wang } \\
\text { (1994) }\end{array}$ & Taiwan & $\begin{array}{l}\text { Higher education had greatest impact compared to primary and } \\
\text { secondary education. }\end{array}$ \\
\hline $\begin{array}{l}\text { Benhabib and } \\
\text { Spiegel (1994) }\end{array}$ & Cross-Country & Positive effects between education and growth \\
\hline $\begin{array}{l}\text { Mingat and Tan } \\
\text { (1998) }\end{array}$ & 113 Countries & $\begin{array}{l}\text { Higher education impacted positively in developed economies; } \\
\text { secondary education impacted positively in developing } \\
\text { economies and primary education impacted positively in less } \\
\text { developed economies }\end{array}$ \\
\hline Gemmell (1996) & OECD Countries & $\begin{array}{l}\text { Primary education most affects the less developed countries } \\
\text { while secondary and higher education affect the developed ones }\end{array}$ \\
\hline Mc Mahon (1998) & Asian Countries & $\begin{array}{l}\text { Primary and secondary levels had significant positive effects on } \\
\text { economic growth while the incidence of higher education is } \\
\text { negative }\end{array}$ \\
\hline $\begin{array}{l}\text { Bill and Klenow } \\
\text { (2000) }\end{array}$ & Cross-Country & $\begin{array}{l}\text { The channel from education to economic growth does not } \\
\text { explain a significant proportion of the relationship between } \\
\text { education and growth. }\end{array}$ \\
\hline Abbas (2001) & $\begin{array}{l}\text { Pakistan and Sri } \\
\text { Lanka }\end{array}$ & $\begin{array}{l}\text { Primary education had a negative effect on growth whereas } \\
\text { secondary and higher education had positive significant impacts } \\
\text { on growth in both countries. }\end{array}$ \\
\hline $\begin{array}{l}\text { Asteriou and } \\
\text { Agiomirgianakis } \\
\text { (2001) }\end{array}$ & Greece & $\begin{array}{l}\text { Increases in enrolment rates for primary, secondary and higher } \\
\text { education positively affected growth }\end{array}$ \\
\hline $\begin{array}{l}\text { Petrakis } \kappa \alpha l \\
\text { Stamatakis (2002) }\end{array}$ & $\begin{array}{l}\text { Low and Middle } \\
\text { Income } \\
\text { Countries }\end{array}$ & $\begin{array}{l}\text { Growth effects of education depend on the level of } \\
\text { development. Low-income countries benefitted from primary } \\
\text { and secondary education while high-income, developed } \\
\text { countries, benefitted from higher education }\end{array}$ \\
\hline $\begin{array}{l}\text { Self and } \\
\text { Grabowski (2004) }\end{array}$ & India & $\begin{array}{l}\text { Primary and secondary education had a strong causal impact on } \\
\text { economic growth }\end{array}$ \\
\hline Bratti et al (2004) & Cross-Country & Primary and secondary education contribute to productivity \\
\hline Villa (2005) & Italy & $\begin{array}{l}\text { Higher and secondary education had positive effect on } \\
\text { economic growth while primary education had no effect. }\end{array}$ \\
\hline $\begin{array}{l}\text { Haouas and } \\
\text { Yagoubi (2005) }\end{array}$ & MENA Countries & $\begin{array}{l}\text { Average human capital significantly influences growth but has } \\
\text { no effect on productivity growth }\end{array}$ \\
\hline Park (2004) & $\begin{array}{l}94 \text { Developed and } \\
\text { Developing } \\
\text { Countries }\end{array}$ & $\begin{array}{l}\text { Educational attainment levels- (human capital) positively } \\
\text { influence productivity growth. }\end{array}$ \\
\hline Lin (2006) & Taiwan & $\begin{array}{l}\text { Primary, secondary and tertiary education, have positive } \\
\text { impacts on economic growth. }\end{array}$ \\
\hline Francais and Iyare & Caribbean- & Causality for Education Expenditure and GDP per Capita \\
\hline
\end{tabular}




\begin{tabular}{|c|c|c|}
\hline (2006) & $\begin{array}{l}\text { Barbados, } \\
\text { Jamaica, and } \\
\text { Trinidad and } \\
\text { Tobago }\end{array}$ & $\begin{array}{l}\text {-Bi-directional in the short-run for Jamaica } \\
\text {-Neutral causality in the short or long run in Barbados, and } \\
\text { Trinidad and Tobago } \\
\text { Countries with higher per capita gross national income (GNI) } \\
\text { seem to be spending more per capita on education }\end{array}$ \\
\hline Chi (2008) & China & $\begin{array}{l}\text { Higher education had positive significant effects on growth than } \\
\text { primary and secondary education. }\end{array}$ \\
\hline $\begin{array}{l}\text { Pereira and Aubyn } \\
\text { (2009) }\end{array}$ & Portugal & $\begin{array}{l}\text { Primary and secondary education had positive impacts on GDP, } \\
\text { while higher education has a small negative effect }\end{array}$ \\
\hline $\begin{array}{l}\text { Loening, Bhaskara } \\
\text { and Singh (2010) }\end{array}$ & Guatemala & $\begin{array}{l}\text { Primary education benefitted growth than secondary and } \\
\text { tertiary education. }\end{array}$ \\
\hline $\begin{array}{l}\text { Shaihani, et al. } \\
\text { (2011) }\end{array}$ & Malaysia & $\begin{array}{l}\text { In the short run, secondary education had positive significant } \\
\text { effects unlike primary and tertiary education. In the long run, } \\
\text { only higher education had a positive significant effect on } \\
\text { growth. }\end{array}$ \\
\hline $\begin{array}{l}\text { Ahmad and French } \\
\text { (2011) }\end{array}$ & Bangladesh & $\begin{array}{l}\text {-GDP granger causes human capital stock; } \\
\text {-Innovations in secondary education have an impact on real } \\
\text { GDP }\end{array}$ \\
\hline Adelakun (2011) & Nigeria & $\begin{array}{l}\text { A strong relationship is apparent between human capital } \\
\text { (primary, secondary and tertiary enrolments) and economic } \\
\text { growth }\end{array}$ \\
\hline Pegkas (2014) & Greece & $\begin{array}{l}\text { Secondary and higher education affected growth positively; but } \\
\text { primary had no impact on education }\end{array}$ \\
\hline
\end{tabular}

Source: Compiled by Authors

In assessing the effects of education (human capital) development on growth for sustainable development, more fundamental issues can be drawn via time horizon impacts. Ahmad and French (2011) in the analysis of human capital and economic growth coined an issue termed "horizon problem" as regards developing economies. This concept emanated from the timely returns of educational investments in (short-run or long-run) tackling developmental issues like unemployment, low income levels and productivity. Therefore, Ahmad and French (2011) argued that while concentrating some resources on minimum or basic education, exploring alternative investment options that will bring quick returns that could address developmental challenges could be a worthwhile framework for developing economies, instead of concentrating resources on higher education.

The position of Ahmad and French (2011) follow Krueger and Lindahl (2001) which posit on the diminishing effects of education in latter stages of development especially in developing economies. They argued that given population increases in countries like Nigeria, minimum education of unskilled and illiterate persons will have greater positive and multiplier effects in 
boosting productivity. Therefore, they opined that (development fallouts from giving basic education and reducing illiteracy) investments in basic education to illiterates will be synonymous to the results that emanate from higher and tertiary education that drive innovation and productivity in developed economies. Besides, they also argued that with minimum education, labour can quickly engender employment thereby reducing the increasing rate of unemployment especially at higher levels, popularly referred to as graduate unemployment. Given the underlying perspective from the extant literature, the question then is, to what extent can the continuous enrolment in education stimulate employment or reduce unemployment burdens in developing economies like Nigeria?

Although several studies have examined the pattern of education in Nigeria, as well as educational expenditures vis-à-vis learning outcomes (Adeyemo, 2000; Moja, 2000; Debalen et al.,2001; Adawo, 2006; Pitanet al., 2012), there is a dearth of studies on the educationemployment interrelationships in Nigeria. Furthermore, while several studies have been conducted on the education-growth nexus, especially in the long run, little attention has been paid to the short-run effects in Nigeria. Therefore, while still incorporating the long-run analysis, this study takes previous studies a step higher. This is achieved by adopting a holistic approach to the education-growth nexus by incorporating short run effects of educational investments in boosting employment vis-à-vis growth channels. This approach is intended to inform policy makers whether to totally align their perspectives solely on the position of the neo-classical and new growth theories on long-run educational impacts or modify their approaches within developing economies to suit both current and future challenges which are both contingent for sustainable development.

\subsection{An Overview of Education Policy in Nigeria: Implications for Employment Status}

Dating back to the 1940s, policies to promote literacy in Nigeria have been ongoing. This ranged from Western adult education programmes to primary, secondary and higher levels of education. Prior to independence in the 1960s, a Free Primary Education (FPE) scheme had been implemented by both the Western and Eastern Regional Governments. Also, as part of government commitment to development through education, by the mid-1970s, there were reengineering policies for free, compulsory and Universal Primary Education (UPE), free secondary education, and free adult literacy programmes in Nigeria (Ihejirika, 2013). This period 
gave rise to the first national policies on education of 1977; which have been reviewed severally (Adeyemi, Oribabor and Adeyemi, 2012). Although the government has introduced the 'laissezfaire' component to all levels of educational acquisition in Nigeria, the government still contributes to educational development in the country via budgetary allocations. Since the mid1970s, budgetary allocations to education have grown from about an average of $2 \%$ to about an average of $8 \%$ in the mid-80s. In the mid-90s it averaged at 7\%; by the year 2000, it was about $12.5 \%$ and between 2010 and 2018, the figure has been an average of 10\% (Central Bank of Nigeria, 2015).

Amongst basic educational acquisition programmes are the nomadic education for migrants, distance or open education intended to increase accessibility and equitability. One of the most popular of these educational programmes is the Universal Basic Education (UBE) programme of 1999, otherwise known as Early Childhood Care and Education (ECCE). The UBE was a buildup on the Universal Primary Education (UPE) of 1977 which aimed at primary school education for all though the UBE programme appeared to be more encompassing. The UBE entails the first nine years of education to include 6 years of primary and 3 years of junior secondary education. Other aspects of the UBE are adult literacy, non-formal education, vocational training, skill acquisition programmes, and education for special groups which include nomads, street children, disabled people and Quranic school children (FRN, 2000; Adeyemi, Oribabor and Adeyemi, 2012). The UBE programme is specially designed as a minimum foundational platform for future build-ups such that, with basic elementary training, a Nigerian child is intellectually armed to make a difference in the society either as an apprentice, self-employed or employed in relevant semi-skilled services like tailoring, bricklaying, shoemaking, inter alia. Specifically, the UBE document purports to equip the individual with knowledge, skills and attitudes in order to enable the attendant individual to live a decent life, carry out civic duties, and become part of societal development. In return, the individual is expected to obtain maximum social, economic and cultural benefits from society (FRN, 2000).

The programme is challenged by financing issues, weak implementation, increasing enrolment despite limited resources and poor societal attitudes. However, the incentives embedded in the programme have accounted for the rising rate of primary enrolment especially amongst the poor (See Figure 1). 
Following to the UBE programme is the senior secondary education which also includes technical colleges, vocational centers, adult education, non-formal education and Islamic education (Adeyemi, Oribabor and Adeyemi, 2012). The design of the UBE programme and the senior school programme explains why several studies have adopted secondary enrolment as a minimum yardstick for human capital development (Gylfason, 2001; Dauda, 2010; Adawo, 2011). Beyond the secondary education is the tertiary form of education. In Nigeria, higher education is available in four main types of institutions which include the: universities, polytechnics, colleges of education and monotechnics. The tertiary education is designed to contribute to national development through relevant high-level manpower training for sophisticated skilled services and employment as well as to engender scholarship, community service, national unity and international understanding.

For all these levels of education, statistics from Figure 1 revealed that the natural growth rates of enrolment follow a linear growth trend; thus, indicating that the enrolment rate for education has continuously risen over the years in Nigeria. Primary enrolment has the highest natural growth rate of about $15 \%$ in the mid-1970s to about $16 \%$ in the year 2000 s. Growth in secondary enrolment followed a natural rate of $11 \%$ in the mid-1970s to about $14 \%$ in the mid-2000s, while tertiary education grew at an average of $12 \%$. These rates justify why the government is hinging on basic education for all via the UBE programme, as it is expected to have a continuum effect for growth and productivity growths in Nigeria. The importance of a basic educational level is underscored by the report of the International Labour Organisation (2012) which showed that the proportion of children in employment was about 40\% in 2007 and 35\% in 2011, while those receiving wages were more than $15 \%$. 


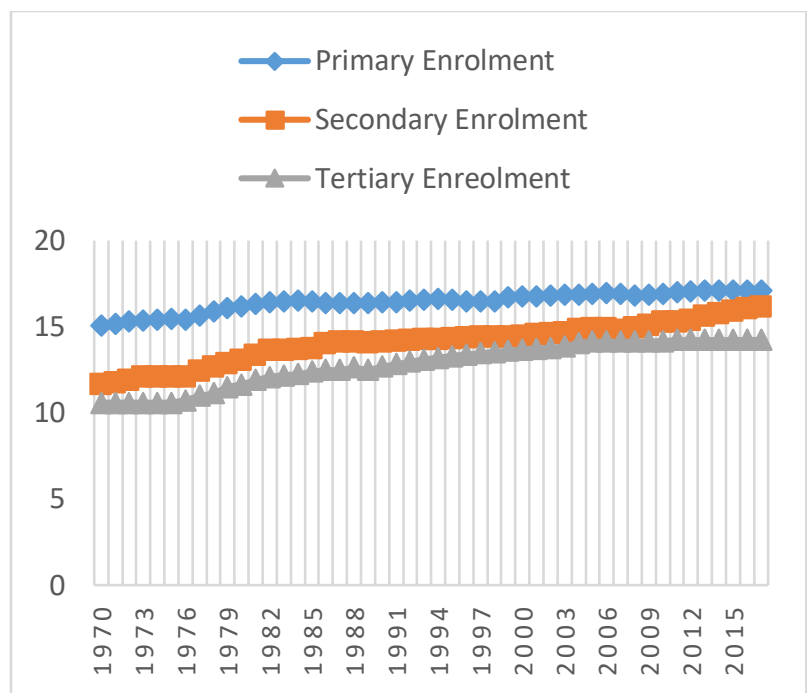

Source: World Development Indicators, 2018

Figure 1: Growth Rates of Educational Enrolments in Nigeria

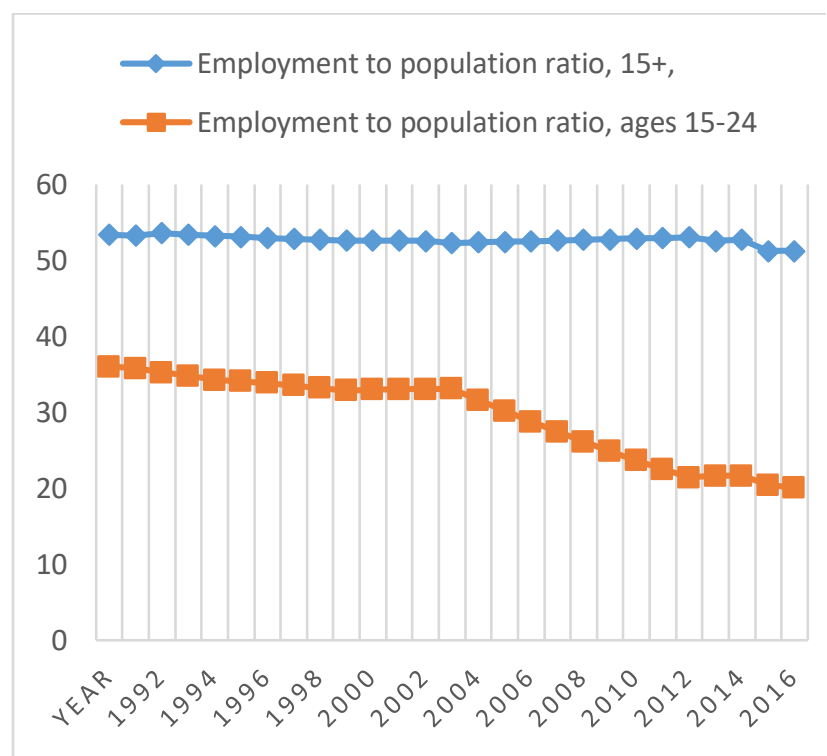

Source: World Development Indicators, 2018

Figure 2: Employment to Population Ratio in

Nigeria

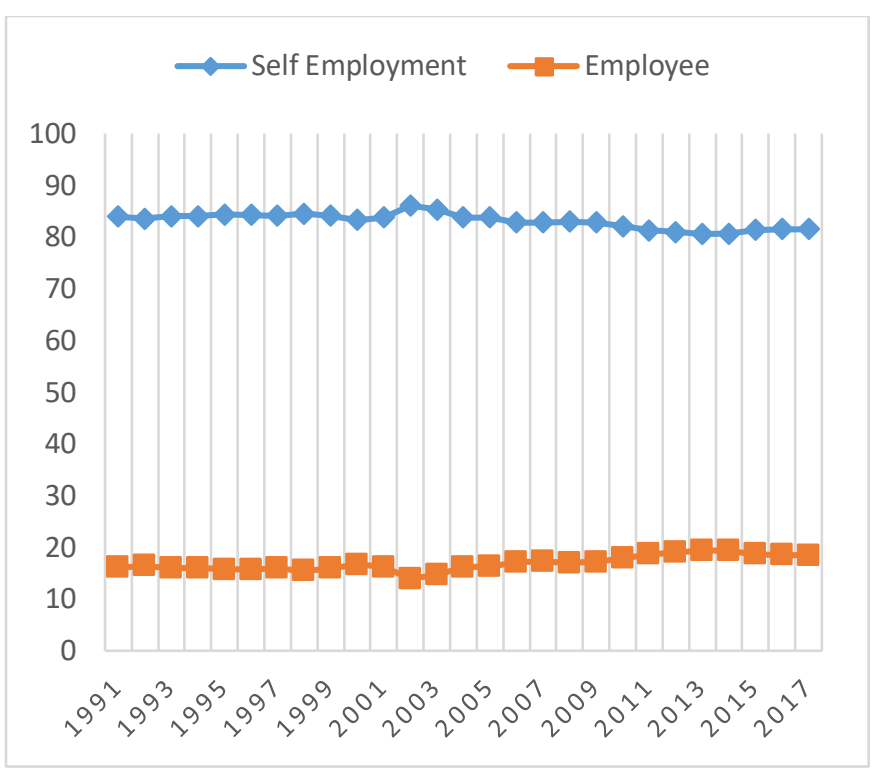

Source: World Development Indicators, 2018

Figure 3: Employment Types in Nigeria

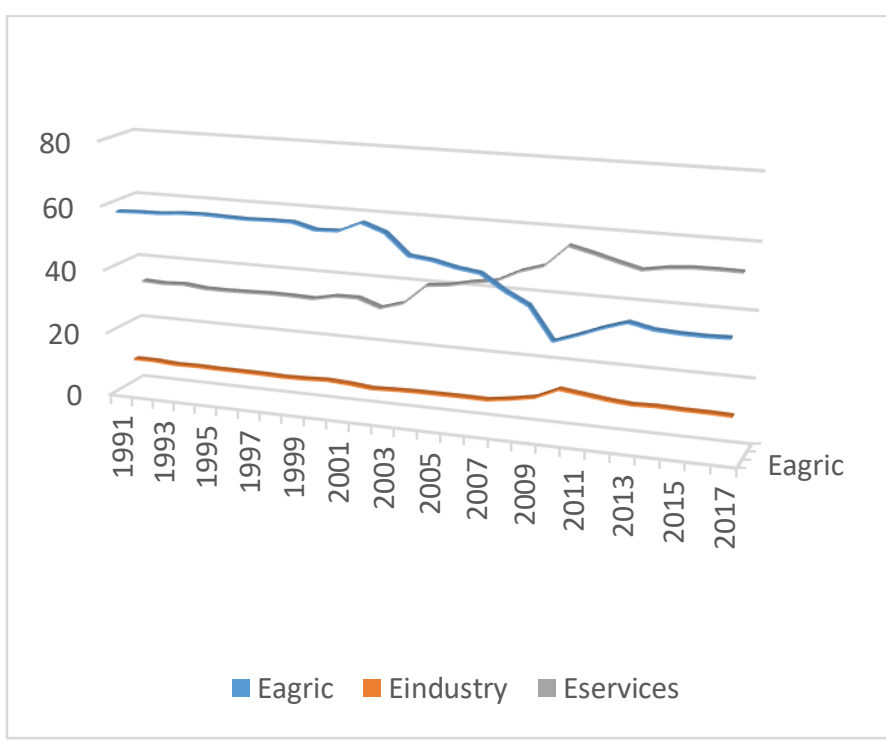

Source: World Development Indicators, 2018

Figure 4: Sectoral Distribution of Employment in Nigeria 
A macro overview of the employment indices using the trend analysis gives a clue to the pattern of employment in Nigeria. For instance, from Figure 2, a steady average employment rate of $50 \%$ is observed for population within the age bracket of 15-24. Incidentally, this age covers the age bracket of persons within the UBE programme. From these statistics, the ease of employment for low to semi-skilled workers can be inferred. This is unlike the declining trend in the employment pattern for the age bracket 15-24 which covers the graduates of senior secondary and tertiary schools. With a declining average employment rate of $35 \%$ in the mid-90s to $25 \%$ in recent times, it is obvious that just like previous studies claimed, the rise of youth unemployment is a major developmental issue. Also studies have stressed the categories of youth unemployment to include graduate unemployment, underemployment and employment mismatch (Okafor, 2011; Ajufo, 2013).

In a further outlook of the employment patterns, Figure 3 reveals the increased rate of selfemployment as against paid employees in Nigeria. Though these self-employments may not necessarily indicate high-level skills, it nonetheless shows the ease of small and medium business start-ups in Nigeria (Akinyemi and Adejumo, 2017) relative to finding paid or whitecollar jobs. Also, Figure 4 gives an insight into the pattern of sectoral distribution of employment in Nigeria. Prior to independence, through to the mid-90s and before the oil boom of the mid$70 \mathrm{~s}$, the agricultural sector had been identified as a major employer with an employment rate of almost $60 \%$ in the mid-90s. However, with a declined rate to about $40 \%$ in 2007 and $35 \%$ in 2010, the employment rate in the agricultural sector has been outmatched by the service sector whose employment rate has risen from $32 \%$ in the mid-90s to $51 \%$ in 2017 . Studies have shown that one of the reasons for this overtake by the service sector is the role information and communication technology (ICT) is playing in advancing service delivery (Oluwatobi and Ogunriola, 2011; Lal 2007; Yekini, Rufai and Adetoba, 2012; Asongu 2013; Tchamyou, 2017, 2019, 2020). Incidentally, between 1991 and 2017, the employment rate within the industrial sector remained at its lowest ebb. With an average of $11 \%$, it can be inferred that innovative and productive activities that can necessitate or increase employment opportunities within the sector are lagging. This is consistent with the findings of previous submissions (Ajayi, 2007; Adejumo 2013a; 2013b). It is worthwhile to go beyond the underlying trends and exploratory insights by engaging a robust analysis from which causality can be inferred. 


\section{Methodology}

\subsection{Theoretical Framework- The New Growth Theory}

This study hinges on the New Growth Theory (NGT) which posits that returns from human capital development (which include skill, knowledge accumulation and health) reinforces growth and productivity that endogenously evolve in a country (Romer, 1990). The NGT is otherwise known as the "endogenous" growth theory because it adopts technology and knowledge into a model of how an economic system operates. Also, the NGT holds that unlike physical capital, knowledge and technology are characterized by increasing returns, and these increasing returns drive the process of growth.

Weil (2013) adds that investment in intellectual ability is not just significant for an increase in output but is critical for a sustainable wage-earning capacity. To synthesize these theoretical constructs of the new growth theory on human capital for development, Robbin (2016) specifically notes that while knowledge contributes to growth, it is also an input to evolving new products and the creation of an output that adds to future input. The implication of this insight is that while human capital is seen as a significant contributor to growth, it is expected to have spillover effects or externalities. These spillovers are expected to reflect in and sustain development outcomes through innovations and opportunities to create employment and wealth in a nation.

\subsection{Data and definitions of variables}

In the macro assessment of employment rates, a mirror position is used for inference via the unemployment statistics. We used annual time series data spanning from 1970-2017 to explore the short-run and long run dynamic relationships and shock responses between educational levels and unemployment for the case of Nigeria. To avoid omitted variable bias in our results, the choice of variables employed is greatly influenced by past empirical studies, stages of economic growth and development experienced in the country and the availability of data.

It is also imperative to note that we decomposed our educational levels into three. Using interactive regressions, we depicted growth-driven education for primary, secondary and tertiary educational levels in order to derive more policy implications from our results. All variables used are transformed into logarithm to avoid the problems of autocorrelation, heteroskedacticity and 
unsound policies. The sources and the description of the variables used in this paper are presented in Table 2 below:

Table 2

Description of Variables

\begin{tabular}{lll}
\hline \hline Variables & \multicolumn{1}{c}{ Definitions } & Sources \\
\hline \hline UMP & $\begin{array}{l}\text { Unemployment as the percentage of } \\
\text { unemployed workers in the total } \\
\text { labour force }\end{array}$ & WDI, 2017 \\
& $\begin{array}{l}\text { Real GDP in constant 2010 US Dollar } \\
\text { as proxy of economic growth }\end{array}$ & WDI, 2017 \\
GDP & $\begin{array}{l}\text { Primary educational enrolment } \\
\text { PRY }\end{array}$ & WDI, 2017 \\
SEC & Secondary educational enrolment & WDI, 2017 \\
TER & Tertiary educational enrolment & WDI, 2017 \\
OPEN & $\begin{array}{l}\text { Trade Openness: sum of export } \\
\text { and import as percentage of GDP }\end{array}$ & WDI, 2017 \\
POPG & $\begin{array}{l}\text { Population growth: change in the } \\
\text { number of individuals in a population } \\
\text { overtime }\end{array}$ & WDI, 2017 \\
& $\begin{array}{l}\text { Government expenditure on } \\
\text { GOV }\end{array}$ & CBN Statistical Bulletin, 2017 \\
& education & \\
\hline \hline SOURCE-WDI: World Development Indicators; CBN: Central Bank of Nigeria &
\end{tabular}

Apart from the variables used as proxies for education enrollment (PRY, SEC, \& TER) and educational investments (GOV), the other control variables to mitigate biasedness in estimation include trade openness and population growth. It has been noted in the literature that the more open an economy, the greater the opportunities that can emerge through trade and investments (that can lead to technology and skill diffusion and cash flow) which can reduce unemployment (Gorzor, 2014). Likewise, population growth can have dual influences on employment. For instance, where population growth is matched with new physical investments, employment is created. However, where the population grows without corresponding investment to support the rising demographic change, unemployment results (Weil, 2013).

\subsection{The Autoregressive Distributed Lag (ARDL) Model}

In this study, to investigate the time dynamic (long run and short run) relationships between education enrollment and unemployment in Nigeria, we employed the Autoregressive Distributed Lag (ARDL) modelling approach initially introduced by Pesaran and Shin (1999) and later extended by Pesaran et al (2001). To the best of our knowledge, it is most appropriate to capture the short run and long run estimations of our model and increase the reliability and 
predictive power of our result for forecasting. ARDL has numerous advantages in comparison with other cointegration approaches ${ }^{1}$. Thus, our unrestricted error correction model (UECM) version of the ARDL model without modulations is formulated as follows:

$$
\begin{aligned}
& \Delta U M P_{t}=\rho_{0}+\sum_{J=1}^{P} \alpha_{j} \Delta U M P_{t-j}+\sum_{j=1}^{q} \beta_{j} \Delta O P E N+\sum_{j=1}^{r} \emptyset_{j} \Delta G D P+\sum_{j=1}^{s} \Psi_{j} \Delta G O V_{t-j}+\sum_{j=1}^{t} \omega_{j} \Delta P O P G_{t-j} \\
& +\sum_{j=1}^{t} \rho_{j} \Delta P R Y_{t-j}+\lambda_{1} O P E N_{t-j}+\lambda_{2} G D P_{t-j}+\lambda_{3} G O V_{t-j}+\lambda_{4} P O P G_{t-j}+\lambda_{5} P R Y_{t-j} \\
& +\mu_{t} \\
& \Delta U M P_{t}=\rho_{0}+\sum_{J=1}^{P} \alpha_{j} \Delta U M P_{t-j}+\sum_{j=1}^{q} \beta_{j} \Delta O P E N+\sum_{j=1}^{r} \emptyset_{j} \Delta G D P+\sum_{J=1}^{s} \Psi_{j} \Delta G O V_{t-j}+\sum_{j=1}^{t} \omega_{j} \Delta P O P G_{t-j} \\
& +\sum_{j=1}^{t} \rho_{j} \Delta S E C_{t-j}+\lambda_{1} O P E N_{t-j}+\lambda_{2} G D P_{t-j}+\lambda_{3} G O V_{t-j}+\lambda_{4} P O P G_{t-j}+\lambda_{5} S E C_{t-j} \\
& +\mu_{t} \\
& \Delta U M P_{t}=\rho_{0}+\sum_{J=1}^{P} \alpha_{j} \Delta U M P_{t-j}+\sum_{j=1}^{q} \beta_{j} \Delta O P E N+\sum_{j=1}^{r} \emptyset_{j} \Delta G D P+\sum_{J=1}^{s} \Psi_{j} \Delta G O V_{t-j}+\sum_{j=1}^{t} \omega_{j} \Delta P O P G_{t-j} \\
& +\sum_{j=1}^{t} \rho_{j} \Delta T E R_{t-j}+\lambda_{1} O P E N_{t-j}+\lambda_{2} G D P_{t-j}+\lambda_{3} G O V_{t-j}+\lambda_{4} P O P G_{t-j}+\lambda_{5} T E R_{t-j} \\
& +\mu_{t}
\end{aligned}
$$

where $\Delta$ is the first difference operator, $\alpha, \beta, \emptyset, \Psi, \omega$ and $\rho$ are the coefficient estimates of the chosen variables; $\mu_{\mathrm{t}}$ is error term; $\mathrm{p}, \mathrm{q}, \mathrm{r}, \mathrm{s}$, and $\mathrm{t}$ are the optimal lag lengths selected based on the optimal length selection criteria. After this, in the second stage of analysis, modulation effects of growth-driven education for employment were assessed by interacting each level of education with growth (that is $\mathrm{PRY} * \mathrm{GDP}$; $\mathrm{SEC} * \mathrm{GDP} \& T E R * G D P$ ) in the ARDL estimates of equations 1, 2 and 3 above.

The three models (1-3) distinguished above is pertinent to capture independently the effects of each enrollment rate and its modulates on employment levels in Nigeria. Several studies have benchmarked human capital development based on secondary school enrollment rate (Dauda,

\footnotetext{
${ }^{1}$ This approach is found to be applicable irrespective of the order of integration of variables, evades the need for pretesting the integration order of variables, allows the variables to have different optimal lag length of deriving a dynamic unrestricted error correction model from the approach via a simple linear transformation and it integrates both the short run dynamics and long run dynamics together without loss of any long run information (see Pesaran et al, 1997 and 2001; Narayan and Smyth, 2005; Akinlo, 2008 and Sung et al, 2017 among others).
} 
2010; Jaiyeoba, 2015; Salami, Isaac, Habila, Salami\& Abutu, 2019). However, this study is interested in independent effects of each enrollment rate (as distinct measures of human capital development) in three different scenarios for the purpose of comparison. Hence, the three models are stated differently as opposed to aggregating them in a single model. This choice of the specification is consistent with both the aims of the study and the imperative to avoid multcollinearity apparent among the educational variables. The approach of distinctive specification is consistent with recent education, lifelong learning and inclusive development literature (Asongu, Nnanna and Acha-Anyi, 2020c; Tchamyou, Asongu and Odhiambo, 2019; Tchamyou, Erreygers and Cassimon, 2019).

The bounds testing approach is founded on the joint F-statistics or Wald statistics for the analysis of cointegration. The asymptotic distribution corresponding to the F-statistics is standard within the remit of the null hypothesis of no cointegration between the variables that are examined.

The null hypothesis and alternative hypothesis of cointegration is stated as:

$H_{0}: \lambda_{1}=\lambda_{2}=\lambda_{3}=\lambda_{4}=\lambda_{5}=0$

$H_{1}: \lambda_{1} \neq \lambda_{2} \neq \lambda_{3} \neq \lambda_{4} \neq \lambda_{5} \neq 0$.

Moreover, Pesaran et al. (2001) provide the scientific community with two sets of critical values for a given level of significance. One of the sets of critical values supposes that all variables that are included in the ARDL model are I(0), whereas the other set is calculated on the basis that the variables are I(1). If the computed test statistic exceeds the upper critical bounds value, then $H_{0}$ or the null hypothesis is rejected. If the F-statistic is situated within the bounds, then the cointegration test becomes inconclusive. However, if the F-statistic is lower than the value of lower bound, then the null hypothesis of no cointegration cannot be rejected.

\subsection{Vector Autoregressive Model (VAR)}

Prior the VAR analysis, it is pertinent to re-affirm the long-run relationship using the multivariate cointegration technique developed by Johansen (1991). Specifically, the Johansen technique for cointegration was also chosen because it is VAR-based and also the evidence that it performed better than a single-equation and alternative multivariate method (Ibrahim, 2000). 
Just like the F-test in the ARDL, the null hypothesis is usually stated such that: there is no cointegrating relationship among the variables. The null hypothesis is rejected if at least one cointegrating relation is established. The decision criterion is usually based on when the test statistic (Max-Eigen values and Trace statistic) exceed the critical values; and when the probability values are less than 0.05 .

Having performed the Johansen cointegration, we examine the dynamic interaction or the response shocks between these variables. Thus, to do this, we employed vector autoregressive model (VAR) introduced by Sims (1980). This model allows all variables to be treated as endogenous variables with no constraint imposed on them and to estimate the dynamic relationship of all endogenous variables, all lagged values of endogenous variable are introduced into the regression model.

Following Zivot and Wang (2006) let $\left.y_{t}=y_{1, t}, y_{2, t} \ldots \ldots y_{n, t}\right)$ be $(\mathrm{n} \times 1)$ vector of time series variables, the basic p-lag vector autoregressive (VAR) model is denoted as follows:

$y_{t}=\emptyset_{0}+\emptyset_{1} y_{t-1}+\cdots .+\emptyset_{p} y_{t-p}+\mu_{t}$.

With $\mathrm{t}=1,2 \ldots \mathrm{T}$, where $\emptyset_{i}$ are $(\mathrm{n} \times \mathrm{n})$ coefficient matrices and $\mu_{t}$ is a $(\mathrm{n} \times 1)$ unobservable zero mean white noise vector process (serially uncorrelated) with time-invariant covariance matrix $\Sigma$ The above equation can be also written as follows:

$\emptyset(L) y_{t}=\emptyset_{t}+\mu_{t}$.

Where $\varnothing(L)=I_{n}-\emptyset_{1} L-\cdots .-\emptyset_{p} L_{p}$. The VAR (p) model is stable if the roots of determinant $(I n-\Phi 1 z-\cdots-\Phi p z p)=0$ lie outside the complex unit circle, or, equivalently, if the eigenvalues of the companion matrix have a modulus less than one.

$F=\left[\begin{array}{cccc}\emptyset_{0} & \emptyset_{0} \ldots & \emptyset_{0} \\ I_{n} & 0 & \ldots & 0 \\ 0 \ldots & \ldots & 0 \\ 0 & 0 & I_{n} & 0\end{array}\right]$

Assuming that the process has been initialized in the infinite past, then a stable VAR (p) process is stationary and ergodic with time-invariant means, variances, and auto-covariances. Thus, a more general form of the VAR (p) model - with deterministic terms and exogenous variables - is given by: 
$y_{t}=\emptyset_{0}+\emptyset_{1} y_{t-1}+\cdots+\emptyset_{p} y_{t-p}+\beta D_{t}+\delta X_{t}+\mu_{t}$.

Where $D_{t}$ is a $(1 \times 1)$ matrix of deterministic components, $X_{t}$ is a $(m \times 1)$ matrix of exogenous variables, and $\beta$ and $\delta$ are parameters' matrices.

\section{Empirical Results and Discussion}

Prior to uncovering the relationship between these variables, it is salient to determine the stationarity of all variables to be used in this study to avoid misleading parameter estimates of the variables using the ADF, PP and KPSS tests. Thus, the results of the unit root tests conducted are presented in Table 3. The results show that all variables are non-stationary at levels and this led us to transform the variables to first difference to obtain reliable statistical analyses of the variables. The results show that all variables become stationary at first difference which implies that the null hypothesis of unit root is rejected for these variables at different levels of significant.

Table 3: Unit Root Tests

\begin{tabular}{lllllll}
\hline \hline \multirow{2}{*}{ Variables } & At level & \multicolumn{5}{c}{ At first difference } \\
\cline { 2 - 7 } & ADF & PP & KPSS & ADF & PP & KPSS \\
\hline \hline UMP & -0.578 & -0.546 & 1.174 & $-5.576^{*}$ & $-4.933^{* *}$ & $2.2057^{* * *}$ \\
PRY & -0.065 & -0.873 & 0.2421 & $-3.098^{* *}$ & $-5.7517^{*}$ & $0.2523^{*}$ \\
POPG & -0.798 & -0.7445 & 0.467 & $-4.187^{* *}$ & $-2.483^{* *}$ & $0.1233^{* * *}$ \\
SEC & -0.504 & -0.5689 & 0.4572 & $-5.499^{*}$ & $-3.966^{*}$ & $0.534^{*}$ \\
RGDP & -0.822 & -0.5743 & 0.416 & $-6.629^{*}$ & $-6.628^{*}$ & $0.1629^{* *}$ \\
TER & -0.996 & -0.178 & 0.1597 & $2.277^{* *}$ & $-4.686^{*}$ & $0.2045^{* *}$ \\
OPEN & -0.331 & -2.410 & 0.245 & $-8.434^{* *}$ & $-8.297^{*}$ & $0.3013^{* *}$ \\
GOV & -0.4342 & -0.444 & 0.8704 & $-10.265^{*}$ & $-11.844^{*}$ & $0.500^{*}$ \\
\hline \hline
\end{tabular}

Source: Authors' Computation: Note: $* * * * * *$ : significance levels at $1 \%, 5 \%$ and $10 \%$ respectively

Table 4:Estimated ARDL Bounds Test

\begin{tabular}{|c|c|c|c|c|c|c|}
\hline Models & Model & F-stat & $\operatorname{ECM}(-1)$ & value $1 \%$ & value $5 \%$ & value $10 \%$ \\
\hline \multirow[t]{2}{*}{ Model 1} & $1,1,3,5,0,0$ & $7.570 * *$ & $-0.93 * *$ & $1(0)=3.41$ & $1(0)=2.62$ & $1(0)=2.26$ \\
\hline & & & $(0.00)$ & $1(1)=4.68$ & $1(1)=3.79$ & $1(1)=3.35$ \\
\hline \multirow[t]{2}{*}{ Model 2} & $1,2,2,5,5,4$ & $7.185^{* *}$ & $-1.27 * *$ & $1(0)=3.41$ & $1(0)=2.62$ & $1(0)=2.26$ \\
\hline & & & $(0.02)$ & $\mathrm{I}(1)=4.68$ & $1(1)=3.79$ & $1(1)=3.35$ \\
\hline \multirow[t]{2}{*}{ Model 3} & $1,4,4,5,5,1$ & $6.269^{* *}$ & $-1.02 * *$ & $1(0)=3.41$ & $1(0)=2.62$ & $1(0)=2.26$ \\
\hline & & & $(0.01)$ & $1(1)=4.68$ & $1(1)=3.79$ & $1(1)=3.35$ \\
\hline
\end{tabular}

Source: Authors' Computation; Note: ** represents significance at the 5\% level. 
From Table 4, the significance of all the models at 5\% using the F-test depicts that variables indeed have a long-run relationship. Having confirmed the cointegration relationship between the variables, we employed ARDL approach introduced by Pesaran et al (2001) to examine the effects of various indicators (i.e. economic growth, three educational levels and control variables) on unemployment rate. The control variables include population growth, trade openness and government expenditure. The results are summarized in Table $5^{2}$.

The results show that population growth significantly contributes to the unemployment rate in Nigeria. This tendency is robust to all the three models at different significance levels. From the long run analysis, the empirical findings imply that an increase in population growth leads to an increase in unemployment rate by $2.21 \%, 6.91 \%$ and $5.07 \%$, respectively. An increase in economic openness reduces unemployment in all the models by $0.008 \%, 0.02 \%$ and $0.023 \%$ respectively, with a significant effect in Model 2. This indicates that economic openness stimulates economic opportunities. Government expenditure on education reduces unemployment in all the models. But economic growth had no long-run effects on employment. For instance, in the long-run analysis, this finding showed that a percentage increase in GDP leads to a $0 \%$ change in unemployment. In the short-run estimates, openness brings about a significant reduction in unemployment in the second lagged period. While this reduction in unemployment via openness is consistent in Model 2, current values of openness reveal insignificant positive effects of openness and unemployment.

Interestingly, while lagged values of GDP increased unemployment except in lag 4 of Model 3, current values of GDP and lagged values of period 2 and 5 reduce unemployment significantly in the short-run. Also, government expenditure on education within Model 1 revealed that unemployment is reduced by $0.00005 \%$ in the short-run and $0.00004 \%$ in the long-run.

Still on Table 5, the models without modulations show that primary enrollment rate does not reduce unemployment both in the short-run and in the long-run while secondary enrollment reduces unemployment in the short-run (current period $=0.09 \%$ and lag 2 period $=0.12 \%$ ) and

\footnotetext{
${ }^{2}$ It should be noted that to obtain the ARDL model results, it is necessary to find the optimal lag length due to sensitivity of ARDL to optimal lag length. The results of the lag selection criterion used for each time period varies and they produced conflicting results. Hence, this paper employs Akaike Information Criterion and Schwartz Information Criterion (SIC) as the appropriate optimal lag length over the other alternatives due to their consistency and parsimonious features in lag length selection, to avoid losing a lot of degrees of freedom. However, to conserve space, the results are not presented in this paper.
} 
in the long-run $(0.02 \%)$. Also, tertiary enrollment reduces unemployment in the short-run current period by $0.84 \%$ and in the long-run period by $0.02 \%$. However, these enrollment effects in improving employment rate are not significant except for the second lag of the secondary enrollment rate. These findings further affirm secondary enrollments as an average benchmark for human capital development (Dauda, 2010). It is such that the expected basic education obtained from the Universal Primary Education (UPE) and Universal Basic Education (UBE) programmes of 6 years and 9 years respectively, can enable trainees assist workers and potential workers in the labour space and even reduce unemployment rate.

Table 5: ARDL Results for Models without Modulations

\begin{tabular}{|c|c|c|c|}
\hline $\begin{array}{l}\text { Dependent Variable } \\
\text { (Ump) }\end{array}$ & $\begin{array}{l}\text { Model } 1 \\
\text { Coeff }\end{array}$ & $\begin{array}{l}\text { Model } 2 \\
\text { Coeff }\end{array}$ & $\begin{array}{l}\text { Model } 3 \\
\text { Coeff }\end{array}$ \\
\hline \multicolumn{4}{|l|}{ Long Run } \\
\hline OPEN & -0.008570 & $-0.027154 * *$ & -0.023222 \\
\hline GDP & 0.000000 & 0.000000 & 0.000000 \\
\hline GOV & -0.000004 & -0.000011 & -0.000022 \\
\hline POPG & $2.215915^{*}$ & $6.915092 *$ & 5.073030 \\
\hline PRY & $0.030674^{*}$ & & \\
\hline SEC & & -0.024328 & \\
\hline TER & & & -0.139045 \\
\hline \multicolumn{4}{|l|}{ Short-Run } \\
\hline $\mathrm{UMP}(-1)$ & 0.065503 & -0.279062 & -0.022600 \\
\hline OPEN & 0.020042 & -0.001273 & 0.017849 \\
\hline OPEN(-1) & $-0.028050 * *$ & -0.018094 & $-0.026388 * * *$ \\
\hline OPEN(-2) & & -0.015363 & -0.003363 \\
\hline OPEN(-3) & & & 0.011675 \\
\hline OPEN(-4) & & & $-0.023520 * * *$ \\
\hline GDP & $-2.83 \mathrm{E}-13^{*}$ & $-2.94 \mathrm{E}-13^{*}$ & $-2.85 \mathrm{E}-13^{* *}$ \\
\hline GDP(-1) & $3.74 \mathrm{E}-14$ & $8.11 \mathrm{E}-14$ & $1.42 \mathrm{E}-13$ \\
\hline GDP(-2) & $1.85 \mathrm{E}-13^{* *}$ & $2.65 \mathrm{E}-13$ & $1.95 \mathrm{E}-13^{* *}$ \\
\hline
\end{tabular}




\begin{tabular}{|c|c|c|c|}
\hline GDP(-3) & $8.61 \mathrm{E}-14$ & & $1.31 \mathrm{E}-13$ \\
\hline GDP(-4) & & & $-1.23 \mathrm{E}-13$ \\
\hline GOV & $-4.91 \mathrm{E}-05^{* * *}$ & $1.50 \mathrm{E}-05$ & $1.34 \mathrm{E}-05$ \\
\hline GOV(-1) & $6.82 \mathrm{E}-05$ & $-1.60 \mathrm{E}-05$ & $3.74 \mathrm{E}-05$ \\
\hline GOV(-2) & $-8.64 \mathrm{E}-05^{* * * *}$ & $-4.45 \mathrm{E}-07$ & $-6.89 \mathrm{E}-05$ \\
\hline $\operatorname{GOV}(-3)$ & $0.000165^{*}$ & $0.000112 * *$ & $0.000114 * * *$ \\
\hline GOV(-4) & $-2.97 \mathrm{E}-05$ & $2.41 \mathrm{E}-05$ & $3.37 \mathrm{E}-05$ \\
\hline GOV(-5) & $-7.17 \mathrm{E} 05^{* *}$ & $-0.000149^{*}$ & $-0.000153 * *$ \\
\hline POPG & $2.070766^{* *}$ & 10.84166 & 7.608380 \\
\hline POPG(-1) & & -19.82524 & -22.45346 \\
\hline POPG(-2) & & -1.913744 & 12.65642 \\
\hline POPG(-3) & & 50.90083 & 33.66942 \\
\hline POPG(-4) & & $-60.62529 * * *$ & -51.43861 \\
\hline POPG(-5) & & $29.46662 * *$ & $25.14553 * *$ \\
\hline PRY & $0.028664 *$ & & \\
\hline SEC & & -0.089439 & \\
\hline SEC(-1) & & 0.038375 & \\
\hline SEC(-2) & & $-0.121287 * * *$ & \\
\hline SEC(-3) & & 0.046823 & \\
\hline SEC(-4) & & 0.094411 & \\
\hline TER & & & -0.841553 \\
\hline $\operatorname{TER}(-1)$ & & & 0.699366 \\
\hline \multicolumn{4}{|l|}{ Diagnostics } \\
\hline Normality & 0.2846 & 0.4973 & 0.3553 \\
\hline Serial & 0.7661 & 0.2993 & 0.144 \\
\hline $\mathrm{ARCH}$ & 0.154 & 0.015 & 0.417 \\
\hline Ramsey & 0.873 & 0.586 & 0.481 \\
\hline
\end{tabular}

note: $* * *, * *, *$ : significance levels at $1 \%, 5 \%$ and $10 \%$ respectively

Source: Authors' Computation using E-views 9.

Finally, to improve the consistency and reliability of our ARDL results, the diagnostic test results are also reported along with the ARDL results in Table 5, while the stability estimates are 
presented graphically. ${ }^{3}$ The results show that there is absence of serial correlation, heteroskedacticity and multicollinearity in the estimated models.

To further achieve the objective of this study, we examine the modulating effects of educationdriven growths on employment in Nigeria. The results are summarized in Table 6.

Table 6: ARDL Results for Models with Modulations

\begin{tabular}{|c|c|c|c|}
\hline $\begin{array}{l}\text { Dependent Variable } \\
\text { (Ump) }\end{array}$ & $\begin{array}{l}\text { Model } 1 \\
\text { Coeff } \\
\end{array}$ & $\begin{array}{l}\text { Model } 2 \\
\text { Coeff } \\
\end{array}$ & $\begin{array}{l}\text { Model } 3 \\
\text { Coeff } \\
\end{array}$ \\
\hline \multicolumn{4}{|l|}{ Long Run } \\
\hline OPEN & 0.001787 & -0.015478 & $-0.029464 *$ \\
\hline GDP & $-0.000000 *$ & -0.000000 & $0.000000^{*}$ \\
\hline GOV & 0.000006 & -0.000009 & $-0.000067 *$ \\
\hline POPG & $2.331268^{*}$ & $5.068024 *$ & 0.920159 \\
\hline PRY & 0.001938 & & \\
\hline PRY*GDP & $0.000000^{*}$ & & \\
\hline SEC & & $0.096360 *$ & \\
\hline SEC*GDP & & 0.000000 & \\
\hline TER & & & $0.819204 *$ \\
\hline TER*GDP & & & $0.000000^{*}$ \\
\hline \multicolumn{4}{|l|}{ Short-Run } \\
\hline $\operatorname{UMP}(-1)$ & $-1.167148^{*}$ & $-1.413551^{*}$ & -0.036469 \\
\hline $\operatorname{UMP}(-2)$ & $-1.085314^{*}$ & 0.065288 & \\
\hline $\operatorname{UMP}(-3)$ & $-0.346627 *$ & 0.017344 & \\
\hline $\operatorname{UMP}(-4)$ & & -0.157266 & \\
\hline $\operatorname{UMP}(-5)$ & & -0.454615 & \\
\hline OPEN & $0.032496^{*}$ & 0.009105 & 0.012845 \\
\hline OPEN(-1) & 0.002983 & 0.012045 & $-0.029536^{*}$ \\
\hline OPEN(-2) & 0.009203 & $-0.041541^{*}$ & -0.013848 \\
\hline OPEN(-3) & -0.008649 & -0.019755 & \\
\hline OPEN(-4) & $-0.029601 *$ & $-0.032506^{*}$ & \\
\hline OPEN(-5) & & $0.027102 * *$ & \\
\hline GDP & $-1.15 \mathrm{E}-12 *$ & $-4.30 \mathrm{E}-13^{*}$ & $7.48 \mathrm{E}-14$ \\
\hline $\operatorname{GDP}(-1)$ & $-4.45 \mathrm{E}-13 * *$ & $2.59 \mathrm{E}-13 * *$ & $1.20 \mathrm{E}-13$ \\
\hline $\operatorname{GDP}(-2)$ & $6.24 \mathrm{E}-13 *$ & $2.36 \mathrm{E}-13 * * *$ & $2.19 \mathrm{E}-13 * * *$ \\
\hline $\operatorname{GDP}(-3)$ & $3.27 \mathrm{E}-13 * *$ & $1.96 \mathrm{E}-13 * *$ & \\
\hline GDP(4) & $-5.98 \mathrm{E}-13^{*}$ & $-6.48 \mathrm{E}-14$ & \\
\hline GDP(5) & & $-4.08 \mathrm{E}-13^{*}$ & \\
\hline GOV & $-9.05 \mathrm{E}-05^{*}$ & $0.000114^{*}$ & $-3.29 \mathrm{E}-05$ \\
\hline GOV(-1) & $8.71 \mathrm{E}-05 * * *$ & $-0.00021 *$ & $3 . .48 \mathrm{E}-05$ \\
\hline GOV(-2) & $-0.000199 *$ & $1.44 \mathrm{E}-05$ & $-0.000122 *$ \\
\hline $\operatorname{GOV}(-3)$ & $0.000226 * * *$ & $7.10 \mathrm{E}-05$ & $0.000189 * * *$ \\
\hline GOV $(-4)$ & & $0.000284 *$ & \\
\hline $\operatorname{GOV}(-5)$ & & $-0.0003 *$ & \\
\hline POPG & $33.87628 * * *$ & 13.102 & 0.953716 \\
\hline POPG(-1) & -39.35853 & -12.1986 & \\
\hline
\end{tabular}

${ }^{3}$ See Appendix 1. 


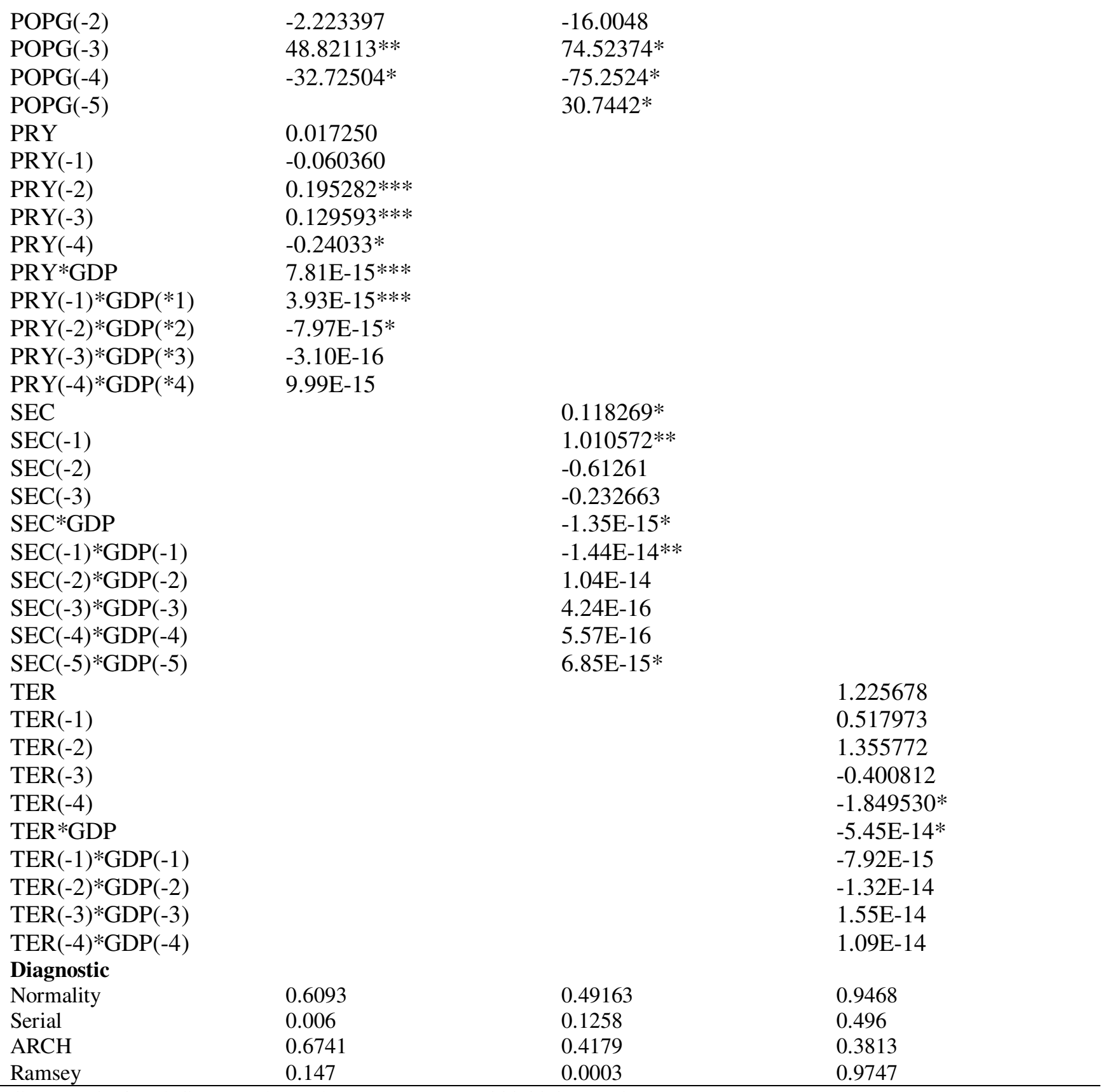

Source: Authors' Computation using E-views $9 . \quad * * *, * *, *$ : significance levels at $1 \%, 5 \%$ and $10 \%$ respectively

With the introduction of the interactive components of growth vis-à-vis educational enrollments, as against current performances, past values of education-driven growth modulate employment at all levels of education enrollment in the short-run. Meanwhile, the presence of interactions via education-driven growth has no effects in modulating employment or unmodulating unemployment in the long-run. The implication of this is that human capital development that is driven by growth (such as the school feeding programmes, creation of grants and scholarship schemes, UBE, inter alia) will result in short-run outcomes related to modulating employment. 
However, if human capital development will be sustained in the long-run, some other associated factors are required. For instance, the World Bank report on human capital (2018) identified some other factors that challenge the long-run outcomes of human capital development. These factors include poor social spending and social safety nets (entailing challenges of fragility, conflict and violence from the activities of bandits and terrorist which result in debility, loss of life and destruction of public properties), corruption in governance and lack of accountability, poor policy implementation and mismatch, inadequate education and health resource allocation, limited technologies, low private sector involvement and inadequate investment to cater for population dynamics (population increase and new employment opportunities).

For robustness checks of the ARDL estimates, the dynamic interactions among these variables are captured using the VAR approach. Following the confirmation of stationarity among the variables, long run relationships between four of the variables $(P R Y, S E C, T E R \& U M P)$ are employed using Johansen and Juslieus (1992) empirical framework.

Table 7: Cointegration Result

\begin{tabular}{lccccc}
\hline \hline $\begin{array}{l}\text { Hypothetical } \\
\text { No of Ce(s) }\end{array}$ & $\begin{array}{l}\text { Eigen } \\
\text { Value }\end{array}$ & $\begin{array}{c}\text { Trace } \\
\text { statistics }\end{array}$ & $\begin{array}{c}\text { Critical } \\
\text { Value }\end{array}$ & \multicolumn{2}{c}{$\begin{array}{c}\text { Maximum } \\
\text { Eigen }\end{array}$} \\
\hline \hline 0 & 0.8358 & 78.22 & 69.81 & 61.42 & 33.87 \\
1 & 0.4560 & 65.79 & 47.85 & 39.68 & 27.58 \\
2 & 0.3475 & 21.10 & 29.79 & 14.51 & 21.13 \\
3 & 0.1512 & 6.587 & 15.49 & 5.577 & 14.26 \\
& & & & & \\
0 & 0.9640 & 80.48 & 69.81 & 70.2 & 38.87 \\
1 & 0.8519 & 72.27 & 47.85 & 40.12 & 27.58 \\
2 & 0.6060 & 27.15 & 29.19 & 20.59 & 21.13 \\
3 & 0.3900 & 12.55 & 15.49 & 10.40 & 14.26 \\
& & & & & \\
0 & 0.989 & 67.34 & 43.85 & 63.42 & 27.58 \\
1 & 0.909 & 48.91 & 50.79 & 49.56 & 51.13 \\
2 & 0.760 & 20.34 & 15.49 & 20.07 & 14.26 \\
3 & 0.240 & 0.340 & 3.842 & 0.687 & 0.354 \\
\hline \hline
\end{tabular}

Source: Authors' Computation using E-views 9. 
The results of the cointegration tests are presented in Table 7. It is apparent from the results that the null hypothesis of no cointegration is rejected since the Trace statistics and the Max Eigen tests exceed the critical value at the $1 \%$ level of significance. The results further show that there is evidence of two cointegrating vectors for primary and secondary education and one cointegrating vector is reported for the tertiary level of education. Thus, just like the ARDL bounds test, we conclude that there is a cointegration relationship between education enrollment rata and employment in Nigeria. Although these relationships appear negative (i.e. as enrollment increases, unemployment increases) in the long-run, the short-run effects are visible.

Having confirmed the long-run relationship amongst the trimmed variables, the ImpulseResponse functions (IRFs) are generated. Specifically, the IRFs again show the time variation in the coefficients and the reactions of the variables to shocks. The graphs of the impulse response simulations are presented in Figure $5^{4}$. It is evident from the graphs that shocks to secondary enrollment (SEC) have medium term effects on unemployment (UMP). This implies that shocks to secondary enrollment reduce employment significantly in the short to medium runs but not in the long-run. Although insignificant, shocks to primary enrollment (PRY) yields negative effects on UMP. A shock to tertiary enrolment (TER) produces no positive employment effects in the short-run, medium-run or long-run.

\footnotetext{
${ }^{4}$ It should be noted that the graphs show the response of each variable to a shock for 10 periods only which is shown on the horizontal axis and it is evidence that the responses converge to zero in the chosen time period.
} 

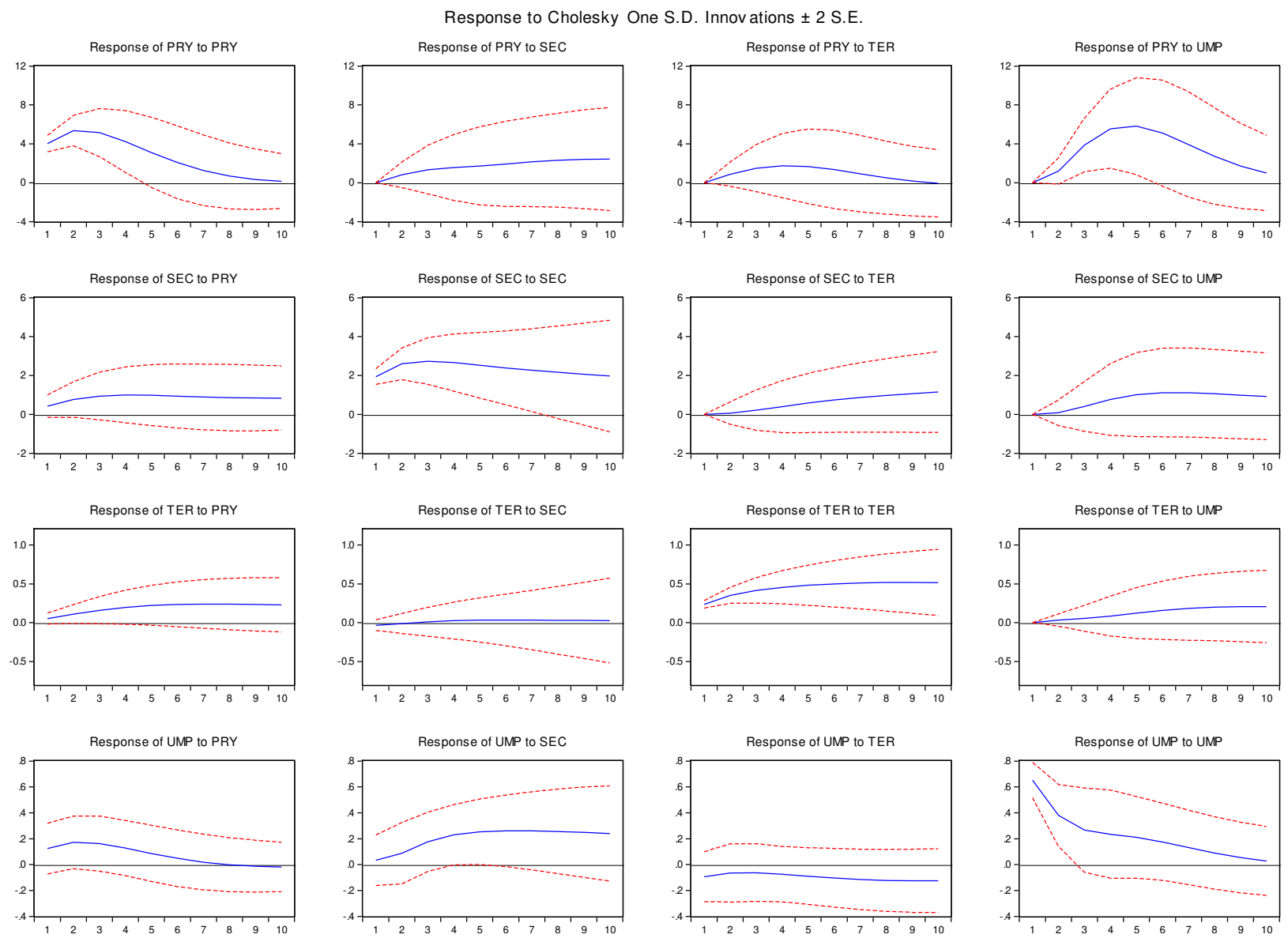

Figure 5. Impulse- ResponseFunctions (IRFs)

We equally present the results of the variance decomposition of the variables. ${ }^{5}$ It is evident from the graphs that influence of past variables such as $P R Y, S E C, T E R$ and UMP shocks on corresponding contemporary variables dominate in the forecast horizon periods. This variance decomposition shows that the influences past variables contribute immensely to corresponding present forecast error variances in Nigeria. For the interested variables, the influences of $P R Y, S E C$ and TER on the unemployment forecast error variance are stronger in the forecast horizon periods from 5-10 than the initial periods of 1-4.

\section{Concluding implications and future research directions}

This study has examined the distinct effects of the different education enrollment levels (as measures of human capital) on employment rates (using the unemployment rate as a proxy) in

${ }^{5}$ See Appendix 2 
Nigeria. The study has gone further to examining modulated effects of education by growth on employment rates, with a view to drawing implications for sustainable human capital in Nigeria.

Findings from the study reveal that unlike primary enrollments, secondary enrollment is a pertinent measure of human capital as it is established to reduce unemployment significantly in the short-run though not significantly in the long-run. The estimates withstand empirical scrutiny when assessed within the framework of VAR analysis. Similarly, tertiary education is seen to reduce unemployment in the short-run and in the long-run though corresponding estimates were not significant. This finding lends credence to the effects of the Universal Basic Education (UBE) programme of the government in checking unemployment to some extent in Nigeria. However, its plausibility in assuring sustainable human development remains to follow the targets of SDG 4 on improving productivity and education outcomes as well as actualizing other SDGs on poverty reduction and inclusive growth. Moreover, with the introduction of the modulations of education driven growths, all the education enrollment rates reduced unemployment significantly in the short-run though these were not visible in the long-run despite the long-run co-movement of the selected variables. Once again, this raises the doubts of education actualizing sustainable dimensions for human capital in Nigeria.

Thus, based on our findings, to actualize sustainable human capital development in Nigeria will require the government looking beyond education as the 'miraclous weapon'. Indeed, education particularly augmented with growth will pass a fundamental mechanism to develop human capital especially as it pertains to reduction in unemployment rates or creating employment. However, to sufficiently sustain human capital development requires the consistency of other associated determinants. It is important to note that the World Bank (2018) has ranked Nigeria 152 out of 157 countries in terms of human development associated determinants for human capital which include social safety nets, good governance, private sector development, efficient utilization of human and physical resources, specialized education and training (like artisanship and technical training), leveraged disruptive technologies and created opportunities through investments for new jobs.

Ultimately, to create employment in the long-run and sustain human capital development in Nigeria, we recommend that while improving on the existing structures of education to increase enrollment rates, the government of the country should look beyond the traditional definition of 
human capital of education, skill and health and improve on the associated determinants of human capital development. The analysis obviously leaves room for improvement especially as it pertains to contributing to the extant literature by assessing how the established findings in this study withstand empirical scrutiny within the framework of other countries. This future research direction builds on the perspective that the findings and corresponding policy implications established in the study cannot be implemented in other developing countries unless such implementation is informed by robust empirical analyses that are specific to attendant countries. 


\section{References}

Abbas, Q. (2001). Endogenous Growth and Human Capital: A Comparative Study of Pakistan and Sri Lanka. The Pakistan Development Review, 40(4), 987-1007

Adawo, M. A. (2011). Has education (human capital) contributed to the economic growth of Nigeria? Journal of Economics and International Finance, 3(1), 46-58.

Asteriou, D., and Agiomirgianakis, G. (2001). Human Capital and Economic Growth, Time Series Evidence from Greece. Journal of Policy Modeling, 23, 481-489.

Akinlo, A. E. (2008). Energy consumption and economic growth: evidence from 11 Sub-Sahara African countries. Energy economics, 30(5), 2391-2400.

Adejumo, A. V., Olomola, P. A., \&Adejumo, O. O. (2013a). The Role of Human Capital in Industrial Development: The Nigerian Case (1980-2010). Modern Economy, 4(10), 639.

Adejumo, A. V. (2013b). Foreign direct investments and manufacturing sector performance in Nigeria (1970-2009). Australian Journal of Business and Management Research, 3(4), 39.

Adejumo, O.O. \&Adejumo, A.V. (2017). An Analysis of Human Capital Development And Productivity Growth- Case Study, Nigeria. Review of Innovation and Competitiveness, 3 (3), 6184. Retrieved from https://hrcak.srce.hr/187210

Adeyemi, B. A., Oribabor, O. A., \&Adeyemi, B. B. (2012). An overview of Educational Issues in Nigeria: Thoughts and Reflections. 2012-12-12]. http://nau.

edu/uploadedFiles/Academic/COE/About/Projects/An\% 20Overview\% 20of\% 20Educational\% 20Issues\% 20in\% 20Nigeria. pdf.

Adeyemo, J. A. (2000). The demand for higher education and employment opportunities in Nigeria. The Dilemma of Post-Colonial Universities: Elite Formation and the Restructuring of Higher Education in sub-Saharian Africa, 182.

Adelakun, O. J. (2011). Human capital development and economic growth in Nigeria. European Journal of Business and Management, 3(9), 29-38.

Ahmad, N., \& French, J. J. (2011). Decomposing the relationship between human capital and GDP: An empirical analysis of Bangladesh. The Journal of Developing Areas, 127-142.

Ajayi, D. D. (2007). Recent trends and patterns in Nigeria's industrial development. Africa Development, 32(2).

Ajufo, B. I. (2013). Challenges of youth unemployment in Nigeria: Effective career guidance as a panacea. African Research Review, 7(1), 307-321.

Akinyemi, F., \&Adejumo, O. (2017). Entrepreneurial Motives and Challenges of SMEs Owners in Emerging Economies: Nigeria \& South Africa. Small, 10, 50. 
Asaju, K., Arome, S., \&Anyio, S. F. (2014). The rising rate of unemployment in Nigeria: the socio-economic and political implications. Global Business and Economics Research Journal, 3(2), 12-32.

Asongu, S. A. (2013). How has mobile phone penetration stimulated financial development in Africa? Journal of African Business, 14(1), 7-18.

Asongu, S. A., Nnanna, J., \& Acha-Anyi, P. N., (2020a). Inequality and gender economic inclusion: the moderating role of financial access in Sub-Saharan Africa. Economic Analysis and Policy, 65, (March), 173-185.

Asongu, S. A., Nnanna, J., \& Acha-Anyi, P. N., (2020b). Finance, inequality and inclusive education in Sub-Saharan Africa. Economic Analysis and Policy, 67(September), 162-177.

Asongu, S., Nnanna, J. \& Acha-Anyi, P. (2020c). Inclusive education for inclusive economic participation: the financial access channel. Gender in Management, 35(5), 481-503.

Barro, Robert J. and Lee, J.-W. (1993). International comparisons of Educational Attainment. Journal of Monetary Economics, Vol 32

Benhabib, J., \& Spiegel, M. M. (1994). The role of human capital in economic development evidence from aggregate cross-country data. Journal of Monetary economics, 34(2), 143-173.

Bils, M., \&Klenow, P. J. (2000). Does schooling cause growth?. American economic review, 90(5), 1160-1183.

Bowen, H. (2018). Investment in learning: The individual and social value of American higher education. Routledge.

Chi, W. (2008). The role of human capital in China's economic development: Review and new evidence," China Economic Review, 19(3), 421-436.

Central Bank of Nigeria (2015). Statistical Bulletin. Central Bank of Nigeria. Abuja

Central Bank of Nigeria (2017). Statistical Bulletin. Central Bank of Nigeria. Abuja

Dauda, R. O. (2009). Investment in education and economic growth in Nigeria: A co-integration approach. In 9th Global Conference on Business and Economics held at University of Cambridge, $U K$.

Dauda, R. O. (2010). Role of human capital in economic development: an empirical study of Nigerian case. In Manuscript, Oxford Business and Economics Conference Program.

Francis, B., \&Iyare, S. (2006). Education and development in the Caribbean: a cointegration and causality approach. Economics Bulletin, 15(2), 1-13.

Gemmell, N. (1996). Evaluating the Impacts of Human Capital Stock and Accumulation on Economic Growth: Some New Evidence. Oxford Bulletin of Economics and Statistics, 58, 9-28. 
Gozgor, G. (2014). The impact of trade openness on the unemployment rate in G7 countries. The Journal of International Trade \& Economic Development, 23(7), 1018-1037.

Gupta, M.R and B. Chakraborty (2004). Human Capital Accumulation and Endogenous Growth in a Dual Economy". Economic Research Unit. Indian Statistical Institute, Kolkata-700108. West Bengal, India.

Grossman, G. M., \&Helpman, E. (1991). Trade, knowledge spillovers, and growth. European economic review, 35(2-3), 517-526.

Gylfason, T. (2001). Natural resources, education, and economic development. European economic review, 45(4-6), 847-859.

Haouas, I., \&Yagoubi, M. (2005). Openness and human capital as sources of productivity growth: An empirical investigation from the MENA countries (No. 1461). IZA Discussion paper series.

Ihejirika, J. C. (2013). Teaching strategies for adult learners: Implications of learning characteristics for effective teaching-learning transaction. Academic Research International, 4(2), 310.

Jaiyeoba, S. V. (2015). Human capital investment and economic growth in Nigeria. African Research Review, 9(1), 30-46.

Johansen, S. (1988). Statistical Analysis of Cointegration Vectors. Journal of Economic Dynamics and Control, Vol. 12, 231-254.

Johansen, S., \&Juselius, K. (1990). Maximum likelihood estimation and inference on cointegration - with applications to the demand for money. Oxford Bulletin of Economics and statistics, 52(2), 169-210.

Krueger, A. B., \&Lindahl, M. (2001). Education for growth: Why and for whom?. Journal of economic literature, 39(4), 1101-1136.

Lal, K. (2007). Globalisation and the adoption of ICTs in Nigerian SMEs. Science, Technology and Society, 12(2), 217-244.

Lin, T.(2006). Alternative Measure for Education Variable in an Empirical Economic Growth Model: Is Primary Education Less Important?," Economics Bulletin, 15, 1-6.

Loening, J., Bhaskara R., and Singh. R. (2010). Effects of Education on Economic Growth: Evidence from Guatemala," MPRA Paper 23665, University Library of Munich, Germany.

Liu, C., \&Armer, J. M. (1993). Education's Effect on Economic Growth in Taiwan. Comparative Education Review, 37(3), 304-321.

Lucas, R. E, 1988. On the Mechanics of Economic Development, Journal of Monetary Economics, 22, 3-42. 
Mankiw, N. G., Romer, D., \& Weil, D. N. (1992). A contribution to the empirics of economic growth. The quarterly journal of economics, 107(2), 407-437.

McMahon, W. W. (2009). Higher learning, greater good: The private and social benefits of higher education. JHU Press.

Mingat, A., Tan, J.-P., 1998. The mechanics of progress in education: evidence from crosscountry data. Policy research working paper no. 2015, World Bank, Washington, DC.

Moja, T. (2000). Nigeria education sector analysis: An analytical synthesis of performance and main issues. World Bank Report.

National Bureau of Statistics (n.d): Social Statistics in Nigeria. 2017, Abuja, Nigeria: National Bureau of Statistics, [http://www.nigerianstat.gov.ng/]

Ndiyo, N. A. (2007). A dynamic analysis of education and economic growth in Nigeria. The Journal of Developing Areas, 41(1), 1-16.

Obadan, M. I., \&Odusola, A. F. (2000, June). Productivity and unemployment in Nigeria. In the proceedings of the Ninth Annual Conference of the Zonal Research Units on productivity and capacity in Nigeria, Central Bank of Nigeria, Abuja.

Okafor, E. E. (2011). Youth unemployment and implications for stability of democracy in Nigeria. Journal of sustainable Development in Africa, 13(1), 358-373.

Oluwatobi, S. O., \&Ogunrinola, O. I. (2011). Government expenditure on human capital development: Implications for economic growth in Nigeria. Journal of sustainable development, 4(3), 72.

Omojimite, B. U. (2010). Education and economic growth in Nigeria: A Granger causality analysis. African Research Review, 4(3).

Pegkas, P. (2014). The link between educational levels and economic growth: A neoclassical approach for the case of Greece. International Journal of Applied Economics, 11(2), 38-54.

Petrakis, P., E., and Stamatakis. D. (2002). Growth and Educational Levels: A Comparative Analysis. Economics of Education Review, 21(5), 513-521.

Pereira, J., and Aubyn M., St (2009). What Level of Education Matters Most For Growth? Evidence From Portugal. Economics of Education Review, 28(1), 67-73.

Pitan, Oluyomi S., and S. O. Adedeji. "Skills Mismatch among University Graduates in the Nigeria Labor Market." Online Submission (2012).

Quah, D and J.E. Rauch (1990). Openness and the Rate of Economic Growth. Journal Development of Studies. Vol. 49 (2). Pp 307-335.

Pesaran, M. H., Shin, Y., \& Smith, R. J. (2001). Bounds testing approaches to the analysis of level relationships. Journal of applied econometrics, 16(3), 289-326. 
Robbins, C. A. (2016). Using new growth theory to sharpen the focus on people and places in innovation measurement. In Blue Sky Forum, Informing Science and Innovation Policies, Towards the Next Generation of Data and Indicators.

Rivera-Batiz, L. A., \&Romer, P. M. (1991). Economic integration and endogenous growth. The Quarterly Journal of Economics, 106(2), 531-555.

Romer, P. M. (1986). Increasing returns and long-run growth. Journal of political economy, 94(5), 1002-1037.

Romer, P. M. (1990). Endogenous technological change. Journal of Political Economy, 98(5, Part 2), S71-S102.

Salami, R. O., Isaac, I., Habila, J., Salami, H., \& Abutu, P. (2019). Gender analysis of access to human capital in Nigeria: A case study of school enrolment. Management, 7(2), 25-31.

Self, Sharmistha, and Richard Grabowski. (2004). Does Education at all Levels Cause Growth? India, a Case Study." Economics of Education Review 23.1 (2004): 47-55.

Shaihani, M., Harisb, A., Ismaila, N., \&Saida, R. (2011). Long run and short run effects on education levels: Case in Malaysia. International Journal of Economic Research, 2(6), 77-87.

Solow, R. M. (1956). A contribution to the theory of economic growth. The quarterly journal of economics, 70(1), 65-94.

Tallman, E., and Wang. P. (1994). Human capital and endogenous growth: evidence from Taiwan. Journal of Monetary Economics, 34, 101-124.

Tchamyou, V. S.(2017). The role of knowledge economy in African business, Journal of the Knowledge Economy, 8(4), 1189-1228.

Tchamyou, V. S. (2020). Education, Lifelong learning, Inequality and Financial access: Evidence from African countries, Contemporary Social Science, 15(1), 7-25

Tchamyou, V.S. (2019). The Role of Information Sharing in Modulating the Effect of Financial Access on Inequality, Journal of African Business, 20(3), 317-338.

Tchamyou, V. S., Asongu, S. A. \& Odhiambo, N. M. (2019). The role of ICT in modulating the effect of education and lifelong learning on income inequality and economic growth in Africa, African Development Review, 31(3), 261-274.

Tchamyou, V. S., Erreygers, G., \& Cassimon, D., (2019). Inequality, ICT and Financial Access in Africa, Technological Forecasting and Social Change, 139(February), 169- 184.

Villa, S. (2005). Determinants of Growth in Italy. A Time Series Analysis," Working Paper, University of Foggia, Italy. 
World Bank (2019), World Development Indicators 2018; World Bank, Washington D.C.

World Bank (2018). Human Capital: A Project for the World. Online Resource: http://documents1.worldbank.org/curated/en/793421540087227031/pdf/Human-Capital-AProject-for-the-World.pdf

Yekini, N. A., Rufai, M. M., Adetoba, B. T., Akinwole, A. K., \&Ojo, O. (2012). ICT Tools for Poverty Eradication and Economic Growth in Nigeria. Greener Journal of Educational Research, 2(1), 013-019. 


\section{Appendix 1}
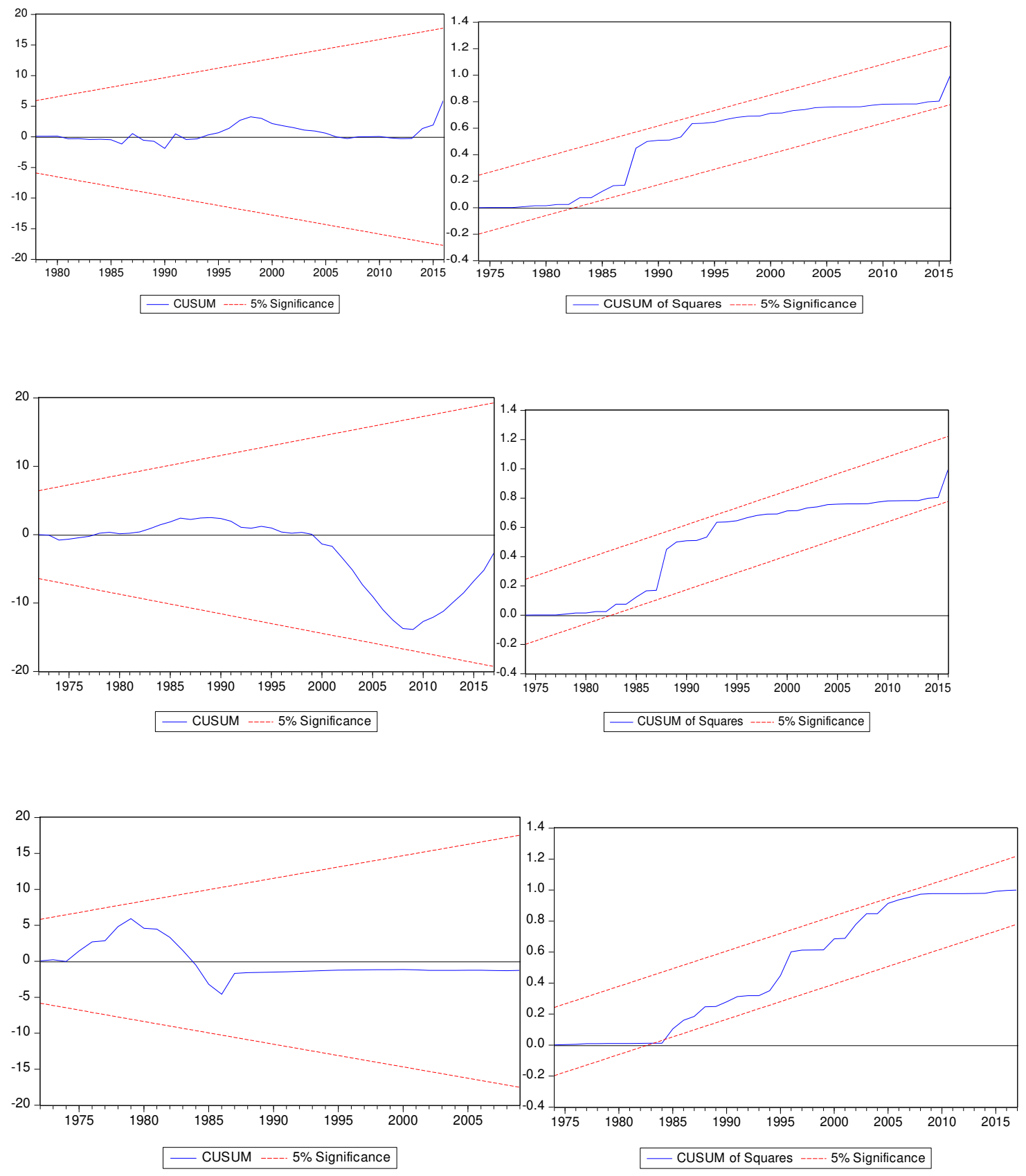


\section{Appendix 2}

Variance Decomposition of the VAR Analysis

\begin{tabular}{|c|c|c|c|c|c|}
\hline \multicolumn{6}{|c|}{$\begin{array}{l}\text { Variance } \\
\text { Decomposition } \\
\text { of PRY: }\end{array}$} \\
\hline 1 & 4.029077 & 100.0000 & 0.000000 & 0.000000 & 0.000000 \\
\hline 2 & 6.912698 & 93.98444 & 1.356803 & 1.612282 & 3.046476 \\
\hline 3 & 9.656773 & 76.54470 & 2.625767 & 3.209928 & 17.61960 \\
\hline 4 & 12.14346 & 60.52882 & 3.309718 & 4.104401 & 32.05706 \\
\hline 5 & 14.02697 & 50.28029 & 3.985879 & 4.500297 & 41.23353 \\
\hline 6 & 15.25001 & 44.39200 & 4.964983 & 4.601041 & 46.04197 \\
\hline 7 & 15.96943 & 41.10304 & 6.326163 & 4.535563 & 48.03523 \\
\hline 8 & 16.38758 & 39.20776 & 8.003678 & 4.402488 & 48.38608 \\
\hline 9 & 16.65738 & 37.98855 & 9.841136 & 4.270443 & 47.89987 \\
\hline 10 & 16.86255 & 37.07835 & 11.66630 & 4.168812 & 47.08654 \\
\hline \multicolumn{6}{|c|}{$\begin{array}{l}\text { Variance } \\
\text { Decomposition } \\
\text { of SEC: }\end{array}$} \\
\hline Period & S.E. & PRY & SEC & TER & UMP \\
\hline 1 & 1.985977 & 4.592545 & 95.40745 & 0.000000 & 0.000000 \\
\hline 2 & 3.360372 & 6.736367 & 93.15967 & 0.038688 & 0.065274 \\
\hline 3 & 4.458394 & 8.273795 & 90.58628 & 0.254240 & 0.885682 \\
\hline 4 & 5.357604 & 9.189276 & 87.41354 & 0.735381 & 2.661798 \\
\hline 5 & 6.115623 & 9.627676 & 84.12475 & 1.470357 & 4.777213 \\
\hline 6 & 6.765130 & 9.785623 & 81.19535 & 2.391029 & 6.628001 \\
\hline 7 & 7.327559 & 9.817416 & 78.77906 & 3.430787 & 7.972740 \\
\hline 8 & 7.820729 & 9.815740 & 76.79540 & 4.549565 & 8.839293 \\
\hline 9 & 8.260251 & 9.827926 & 75.08271 & 5.733013 & 9.356347 \\
\hline 10 & 8.659210 & 9.874559 & 73.48922 & 6.982543 & 9.653676 \\
\hline \multicolumn{6}{|c|}{$\begin{array}{l}\text { Variance } \\
\text { Decomposition } \\
\text { of TER: }\end{array}$} \\
\hline Period & S.E. & PRY & SEC & TER & UMP \\
\hline 1 & 0.243483 & 4.618171 & 1.880702 & 93.50113 & 0.000000 \\
\hline 2 & 0.442276 & 7.453261 & 0.643403 & 91.34498 & 0.558360 \\
\hline 3 & 0.629872 & 10.09453 & 0.349773 & 88.53077 & 1.024929 \\
\hline 4 & 0.806765 & 12.16921 & 0.322820 & 85.77049 & 1.737481 \\
\hline 5 & 0.973808 & 13.57492 & 0.337968 & 83.30506 & 2.782053 \\
\hline 6 & 1.131011 & 14.39997 & 0.340543 & 81.24287 & 4.016619 \\
\hline 7 & 1.277687 & 14.80982 & 0.330354 & 79.62581 & 5.234014 \\
\hline 8 & 1.413201 & 14.96284 & 0.315619 & 78.43425 & 6.287290 \\
\hline 9 & 1.537496 & 14.97546 & 0.301439 & 77.60399 & 7.119113 \\
\hline 10 & 1.651176 & 14.92093 & 0.289556 & 77.05321 & 7.736300 \\
\hline \multicolumn{6}{|c|}{$\begin{array}{l}\text { Variance } \\
\text { Decomposition } \\
\text { of UMP: }\end{array}$} \\
\hline Period & S.E. & PRY & SEC & TER & UMP \\
\hline
\end{tabular}




\begin{tabular}{cccccc}
\hline \hline 1 & 0.671834 & 3.345985 & 0.234132 & 1.971910 & 94.44797 \\
2 & 0.798038 & 6.998485 & 1.359720 & 2.072382 & 89.56941 \\
3 & 0.876502 & 9.205828 & 5.120544 & 2.233373 & 83.44025 \\
4 & 0.947426 & 9.673421 & 10.25011 & 2.535569 & 77.54090 \\
5 & 1.010524 & 9.221969 & 15.27241 & 3.016802 & 72.48881 \\
6 & 1.064107 & 8.518774 & 19.74438 & 3.669111 & 68.06774 \\
7 & 1.109380 & 7.864411 & 23.65054 & 4.450935 & 64.03412 \\
8 & 1.148549 & 7.337491 & 27.02434 & 5.293906 & 60.34426 \\
9 & 1.183248 & 6.926797 & 29.89304 & 6.119333 & 57.06083 \\
10 & 1.214195 & 6.600991 & 32.30020 & 6.859575 & 54.23923 \\
\hline \hline
\end{tabular}

